\title{
MODELLING OF A FERMENTATION PROCESS TO OBTAIN ALCOHOL FROM HYDROLYZED OF CASSAVA
}

\section{MODELAGEM DE UM PROCESSO DE FERMENTAÇÃO PARA OBTER ÁLCOOL A PARTIR DE HODRILIZADO DE MANDIOCA}

\author{
Laís Koop ${ }^{1}$; Marco Aurélio Praxedes ${ }^{2}$ \\ ${ }^{1}$ Universidade Federal do Paraná - UFPR - Curitiba - Brasil \\ ${ }^{2}$ Universidade Estadual de Ponta Grossa - UEPG - Ponta Grossa - Brasil praxedes@uepg.br
}

\begin{abstract}
Abstrac
The following work is about the creation of two computer programs, one for simulation and one for parameter estimation of fermentation processes from cassava hydrolyzed in a batch system. The first program estimates the biomass, substrate and product concentration at different times during a fermentation process. The other program performs adjustments at the mathematical model to provide great kinetics parameters from the comparison among data calculated by the program and data obtained in the literature. Based on comparison of results with literature data, it can be stated that the programs provide a true representation of the fermentation process. The structure of the programs developed allows its use for simulating and providing data of different fermentation processes changing only the input data and equations involving the kinetics.
\end{abstract}

Key-words: alcoholic fermentation, computer simulation, hydrolyzed of cassava, parameter estimation.

\section{Introduction}

Currently, the concern for biological and economic issues has led to increasing research on improving ethanol production by biotechnological routes. These routes are an alternative to production and consequent consumption of petroleum based fuels (ALFENORE et al., 2004 and BORGES, 2008). Besides biofuels significantly reduce the impact of burning fossil fuels on the environment, they are still an alternative to avoid shortages of petroleum, which is non-renewable resource (DIEHL, 2009). Biofuels in worldwide commercial use are biodiesel and, in larger quantities, ethanol (LEITE and LEAL, 2007).

Ethanol is produced by a chemical process called fermentation. In this process, any product containing sugar or other carbohydrate constitutes the raw material for obtaining ethanol (BORZANI et al., 1992). 
Mathematical tools have been used to facilitate the qualitative understanding of the fermentation. Among them, descriptions of real phenomena and processes called mathematical models, characterize the same when its inputs are known (MELLO and PINTO, 2008 and RANZAN et al., 2009). Mathematical modeling of different fermentation processes can be observed in the work of Borges (2008), Henriques et al. (1999), Matos et al. (2009), Ranzan et al. (2009), Reis (2009), Tosetto (2002).

Ranzan et al. (2009) reviews the proposed models for continuous glucose fermentation with Zymomonas mobilis. Henriques et al. (1999) also modeled the process of fed-batch fermentation, and then, from the results obtained, was determined the optimum profile of the wort feed. Reis (2009) used experimental data to validate the model proposed by Hall et al (1978). He simulated a bench bioreactor with fuzzy algorithm implemented in Matlab. The supervisor interface was developed in LabVIEW platform.

The model used in this study simulates the biomass, substrate and product concentration at different times during a fermentation process from hydrolyzed of cassava.

The use of cassava as a carbohydrate source for ethanol production has become a reference to the sugar cane culture because it competes with not inconsiderable advantages (Camacho, 2009).

Salla \& Cabello (2010) confirmed that cassava consumes less energy than cane sugar in the categories: energy expenditure for agronomic production, industrial processing of raw materials per liter of ethanol produced, resulting in a final energetic more favorable.

To perform this simulation we developed a computer program in FORTRAN, using the Runge-Kutta $4^{\text {th }}$ order method for the integration of ordinary differential equations.

The Runge-Kutta method was also used in the work of Diehl (2009), Matos et al. (2009) and Pacheco (2010).

Matos et al. (2009) used the Runge-Kutta method in the FORTRAN programming language to model an oscillatory continuous reactor of production of biodiesel. Diehl (2009) made use of formulation of Runge-Kutta to analyze a continuous bioreactor of biosynthesis of ethanol by Zymomonas mobilis. Pacheco (2010) used fourth-order algorithm of Runge-Kutta method to integrate the set of ordinary differential equations that describe the behavior of the answers of biomass, substrate and product concentration related to changes in the operating conditions of a tower bioreactor operating in loop.

However, for the formulation of mathematical models that simulate adequately fermentation processes, are found many difficulties due to the need to incorporate a number of features that distinguish them from conventional chemical processes (BORZANI et al., 2001 and BUENO, 2006). Thus, among the various steps necessary to perform the modeling, stands out for its difficulty, obtaining kinetic parameters that best fit to the available data (AUGUSTO et al. and 
BORGES, 2008). To this end, we developed an adjustment program that provides kinetics parameters from the comparison among data calculated by the program and data obtained by the literature (BORZANI et al., 2001).

The parameter adjustment of a kinetic model was also used by Borges (2008), Andrietta et al. (2003) and Tosetto (2002).

Borges (2008) estimated the kinetic parameters from experiments in batch and fed batch technique by Differential Evolution (DE) in Matlab. Andrietta et al. (2003) adjusted the parameters of a kinetic model used in the simulation for determining the time of fermentation, but in Delphi. Tosetto (2002) also calculated kinetic parameters from a routine adjustments Delphi 5.0. In their work evaluated the influence of raw material in the kinetic behavior of yeast in ethanol production.

\section{Computational Model}

\subsection{Simulation Program}

The simulation program was developed for a reactor used in alcoholic fermentation from hydrolyzed of cassava in a batch system. The program was developed in FORTRAN and uses the numerical method of integration of systems of ordinary differential equations Runge-Kutta. These differential equations express the variation of the concentration of the biomass $(X)$, the substrate $(S)$ and the product, $(P)$ along different times $(t)$ during the fermentation process. Providing the data (or conditions) of the initial process, the program provides the final stages of fermentation at the desired time. The data and the equations were derived from Borzani et al. (2001).

The differential equations mentioned above are shown below:

$$
\begin{aligned}
\frac{d X}{d t} & =\mu_{x} X \\
\frac{d S}{d t} & =\left(\frac{1}{Y_{X / S}} \mu_{x} X+\frac{1}{Y_{P / S}} \mu_{p} X\right) \\
\frac{d P}{d t} & =\mu_{p} X
\end{aligned}
$$

Wherein, $Y_{X / S}$, is the factor of conversion of substrate to cells (biomass yield) and $Y_{P / S}$, is the factor of conversion of substrate to product (product yield). The specific growth rate $\left(\mu_{x}\right)$ used for calculating the concentration of biomass and substrate in function of time by the equations above and, the specific velocity of product formation $\left(\mu_{p}\right)$ used for calculating the concentration of substrate and product according to the time, is determined by: 
$\mu_{x}=\left(\frac{\mu_{x a} S}{K_{s}+S+\left(S^{2} / K_{i}\right)}\right)^{-K_{P} P}$

$\mu_{p}=\left(\frac{\mu_{p a} S}{K_{s}{ }^{\prime}+S+\left(S^{2} / K_{i}^{\prime}\right)}\right)^{-K_{P}{ }^{\prime} P}$

Wherein, $\mu_{x a}$ is the maximum specific-velocity of microorganism growth, $K_{s}$ is the saturation constant, $K_{i}$ is the inhibition constant of cell growth by the substrate, $K_{p}$ is the inhibition constant of cell growth by the product, $\mu_{p a}$ is the maximum specific-velocity of product formation, $K_{s}$ ' is the substrate concentration in which the specific-velocity of product formation is half of its maximum value, $K_{i}$ ' is the inhibition constant of product formation by the substrate and $K_{p}{ }^{\prime}$ is the inhibition constant of product formation by the product.

\subsection{Process Conditions}

The values of the constants used in the simulation program are detailed in Table 1.

Table 1. Values of the kinetic parameters used in the simulation program

\begin{tabular}{ll}
\hline Parameter & Value \\
\hline Maximum specific-velocity of microorganism growth, $\mu_{x a}\left(\mathrm{~h}^{-1}\right)$ & 0,672 \\
Maximum specific-velocity of product formation, $\mu_{p a}\left(\mathrm{~h}^{-1}\right)$ & 2,08 \\
Saturation constant, $K_{s}\left(\mathrm{~g} \mathrm{~L}^{-1}\right)$ & 6,16 \\
Substrate concentration in which the specific-velocity of product formation is half of its maximum value, $K_{s}^{\prime}$ & 7,88 \\
$\left(\mathrm{~g} \mathrm{~L}^{-1}\right)$ & \\
Inhibition constant of cell growth by the substrate, $K_{i}\left(\mathrm{~g} \mathrm{~L}^{-1}\right)$ & 347 \\
Inhibition constant of product formation by the substrate $K_{i}^{\prime}\left(\mathrm{g} \mathrm{L}^{-1}\right)$ & 37,4 \\
Inhibition constant of cell growth by the product, $K_{p}\left(\mathrm{~g} \mathrm{~L}^{-1}\right)$ & 0,0436 \\
Inhibition constant of product formation by the product, $K_{p}{ }^{\prime}\left(\mathrm{g} \mathrm{L}^{-1}\right)$ & 0,0153 \\
Biomass yield, $Y_{X / S}\left(\mathrm{~g} \mathrm{~g}^{-1}\right)$ & 0,215 \\
Product yield, $Y_{P / S}\left(\mathrm{~g} \mathrm{~g}^{-1}\right)$ & 0,511 \\
\hline
\end{tabular}

Source: BORZANI et al., 2001.

\subsection{Parameter Adjustment Program}

After the development of the simulation program, was up then the creation of a new program capable of adjusting data for the earlier simulated process.

The adjustment program consists in initially test different values for the stoichiometric conversion factor $\left(Y_{X / S}\right)$ of substrate for product and kinetic parameters to be adjusted $\left(K_{s}, K_{s}{ }^{\prime}, \mu_{p a}\right.$, $\left.\mu_{x a}\right)$. The user must provide initial estimates of these parameters, so that the numerical method can be started. These values are systematically renewed by the program until they are optimized. For all the different tests, the program calculates the concentrations of biomass, substrate and product, all as a function of time by solving ordinary differential equations by the Runge-Kutta method. These 
concentrations are then considered as theoretical values calculated by the program. These theoretical results are compared with literature data (experimental) provided to the program, which changes the parameters to be adjusted until the difference (or factorial, or error) between the experimental and theoretical values is minimal. This adjustment is made by the method of minimization functions Quasi-Newton gradient and finite differences.

The equation that determines the error generated is shown below:

$$
\begin{aligned}
& F=\sum_{13}^{l} A(I) \\
& A(I)=\left(\frac{X_{T}(I)-X_{E}(I)}{X_{E}(I)}\right)^{2}+\left(\frac{S_{T}(I)-S_{E}(I)}{S_{E}(I)}\right)^{2}+\left(\frac{P_{T}(I)-P_{E}(I)}{P_{E}(I)}\right)^{2}
\end{aligned}
$$

Where, $X_{T}, S_{T}$ and $P_{T}$ are the theoretical values for the respective concentration of the biomass, of the substrate and the product in a given time $(I)$ and, $X_{E}, S_{E}$ and $P_{E}$ are the experimental values.

Regarding the adjustments program, this one differs from the simulation program, since for any calculation of specific growth rates of microorganisms $\left(\mu_{x}\right)$ and product formation $\left(\mu_{p}\right)$ was disconsidered from the equation the term that considers the inhibition constant of cell growth by the product. This difference was essential to characterize the kinetics of the process later. Thus, it has that, in the adjustments program, $\mu_{x}$ and $\mu_{p}$ were calculated as follows:

$$
\begin{aligned}
& \mu_{x}=\left(\frac{\mu_{x a} S}{K_{s}+S+\left(S^{2} / K_{i}\right)}\right) \\
& \mu_{p}=\left(\frac{\mu_{p a} S}{K_{s}{ }^{\prime}+S+\left(S^{2} / K_{i}^{\prime}\right)}\right)
\end{aligned}
$$

The derived which represent the concentration of biomass, of substrate and product remained identical to the simulation program.

\section{Results and Discussion}

The results and discussion of the simulation program and of the adjustments program are shown separately for clarity. In the topic of the simulation will be presented tables with the results of the simulation program and graphics that compare the data provided by the program with those obtained in the literature. In the item regarding the results and discussion of the optimization 
program will be displayed a table that provides a comparison of the kinetic parameters provided by the program, and their values removed from the literature.

\subsection{Simulation}

A simulation and an optimization program were developed to modeling a fermentation processes from cassava hydrolyzed in a batch system. The similarity between the results of the simulation program and experimental data taken from the literature, made it be possible to predict response of the reactor to changes in operating conditions and scaling. The optimization program also brought satisfactory results that allowed the modeling of the process.

To display the results provided by the different simulation tests will be exposed graphics which contain the concentrations of the biomass, of the substrate and the product at different times of the fermentation process. The different tests differ by the variation of the initial concentration of any of the dependent variables (biomass, substrate or product) and the variation in time of the fermentation process. Table 2 shows the results obtained by the program when the initial concentration of biomass is $1,12 \mathrm{~g} \mathrm{~L}^{-1}$, substrate is $227 \mathrm{~g} \mathrm{~L}^{-1}$, and product is $2,02 \mathrm{~g} \mathrm{~L}^{-1}$.

Table 2. Simulation result for the concentration of the biomass, substrate and product for different times of the cassava hydrolyzate fermentation process

\begin{tabular}{cccc}
\hline Time $(\mathrm{h})$ & Biomass $\left(\mathrm{g} \mathrm{L}^{-1}\right)$ & Substrate $\left(\mathrm{g} \mathrm{L}^{-1}\right)$ & Product $\left(\mathrm{g} \mathrm{L}^{-1}\right)$ \\
\hline 1,00 & 1,61 & $22,4.10$ & 2,40 \\
2,00 & 2,31 & $22,0.10$ & 2,96 \\
3,00 & 3,28 & $21,3.10$ & 3,76 \\
4,00 & 4,61 & $20,5.10$ & 4,91 \\
5,00 & 6,39 & $19,4.10$ & 6,54 \\
6,00 & 8.69 & $17,8.10$ & 8,85 \\
7,00 & 11,5 & $15,9.10$ & 12,1 \\
8,00 & 14,7 & $13,5.10$ & 16,5 \\
9,00 & 18,1 & $10,8.10$ & 22,4 \\
10,00 & 21,3 & 78,1 & 30,1 \\
11,00 & 23,9 & 46,5 & 40,0 \\
12,00 & 25,7 & 14,4 & 52,3 \\
13,00 & 26,2 & 0,147 & 58,4 \\
\hline
\end{tabular}

Figure 1 shows how the results provided by the program well represents the profiles of the concentrations of the variables involved in the fermentation process. It can be seen that as the biomass concentration increases, the substrate is consumed and product is formed.

Through the same image, it is also possible to notice the similarity between the results obtained by the program and the data provided by the literature. These in turn are experimental data that were generated assuming a random error obeying a normal distribution (mean 0,0 and standard deviation $=1,0$ ) of $10 \%$ to the measures of $X$ and $5 \%$ for $S$ and $P$ measures (BORZANI et al., 2001). 
Figure 1. Biomass concentration $X\left(\mathrm{~g} \mathrm{~L}^{-1}\right)$, substrat concentration $S\left(\mathrm{~g} \mathrm{~L}^{-1}\right)$ and product concentration $P\left(\mathrm{~g} \mathrm{~L}^{-1}\right)$ in function of time $(\mathrm{h})$ in an ethanol production process from hydrolyzed of cassava. $(-)$ Trendline representing the values obtained by the program; $(\bullet)$ Values obtained by literature
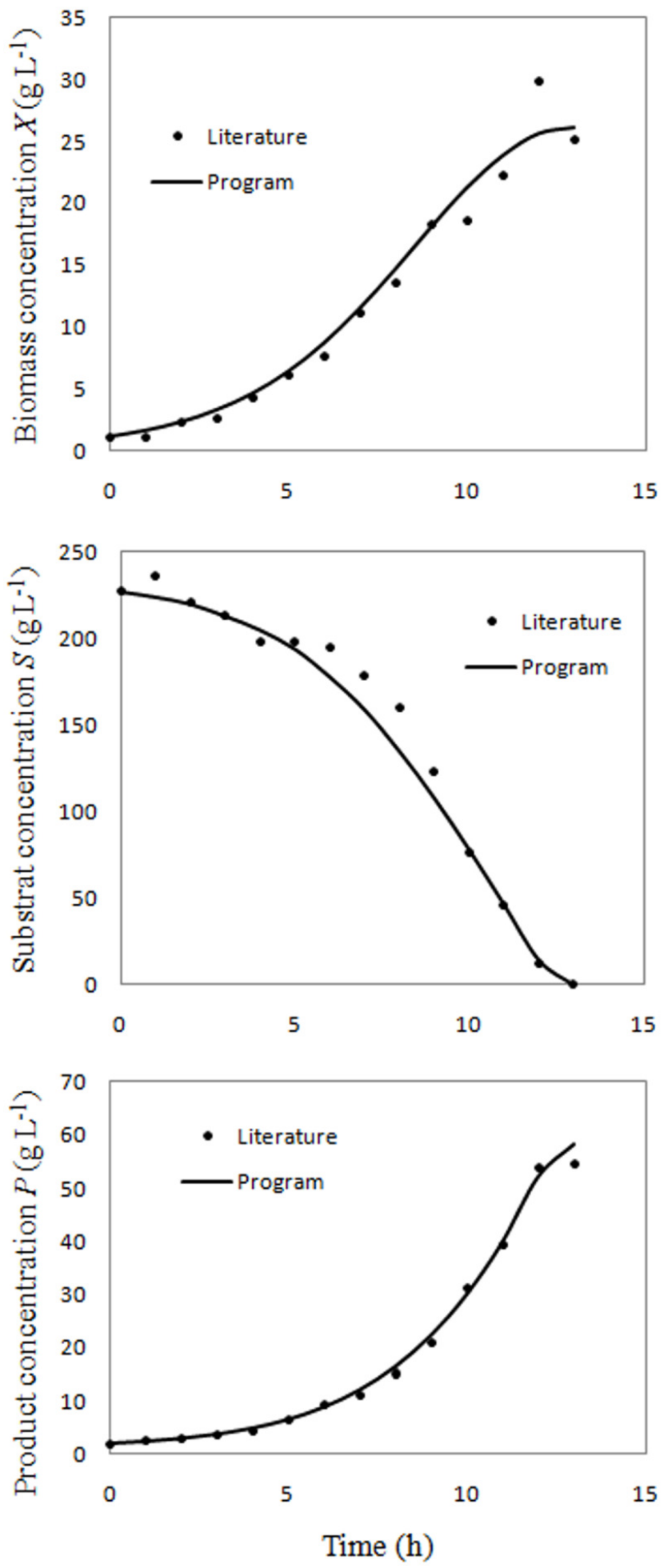

Source: BORZANI et al., 2001.

Performing a test with a higher process time (16 hours), there were obtained the results shown in Table 3. The results show that, after 13 hours of fermentation there were no more biomass growth or product formation, and the small increase in the consumption of the substrate is 
negligible. Thus, it is possible to say that the process can be completed in 13 hours and that by increasing this time, have additional costs in production without significant increase in production.

Table 3. Simulation result for the concentration of the biomass, substrate and product for different times of the cassava hydrolyzate fermentation process, considering that the same happens in 16 hours

\begin{tabular}{cccc}
\hline Time $(\mathrm{h})$ & Biomass $\left(\mathrm{g} \mathrm{L}^{-1}\right)$ & Substrate $\left(\mathrm{g} \mathrm{L}^{-1}\right)$ & Product $\left(\mathrm{g} \mathrm{L}^{-1}\right)$ \\
\hline 0 & 1,12 & 227 & 2,02 \\
1 & 1,61 & 224 & 2,40 \\
2 & 2,31 & 220 & 2,96 \\
3 & 3,28 & 213 & 3,76 \\
4 & 4,61 & 205 & 4,91 \\
5 & 6,39 & 194 & 6,54 \\
6 & 8.69 & 178 & 8,85 \\
7 & 11,5 & 159 & 12,1 \\
8 & 14,7 & 135 & 16,5 \\
9 & 18,1 & 108 & 22,4 \\
10 & 21,3 & 78,1 & 30,1 \\
11 & 23,9 & 46,5 & 40,0 \\
12 & 25,7 & 14,4 & 52,3 \\
13 & 26,2 & 0,147 & 58,4 \\
14 & 26,2 & $2,13 \mathrm{E}-4$ & 58,4 \\
15 & 26,2 & $4,92 \mathrm{E}-6$ & 58,4 \\
16 & 26,2 & $1,16 \mathrm{E}-7$ & 58,4 \\
\hline
\end{tabular}

Evaluating program responses to different tests of initial concentrations of biomass, substrate and product were obtained different results which will be discussed next.

By doubling up the initial concentration of biomass was possible to achieve the results shown in Table 4, whereby, it appears that from eleven hours of fermentation, the whole substrate has been substantially consumed and there is no more product formation. Thus, doubling the initial concentration of biomass, reduces the process time in two hours.

Table 4. Simulation result for the concentration of the biomass, substrate and product for different times of the cassava hydrolyzate fermentation process, considering a different initial concentration of biomass

\begin{tabular}{cccc}
\hline Time $(\mathrm{h})$ & Biomass $\left(\mathrm{g} \mathrm{L}^{-1}\right)$ & Substrate $\left(\mathrm{g} \mathrm{L}^{-1}\right)$ & Product $\left(\mathrm{g} \mathrm{L}^{-1}\right)$ \\
\hline 0 & 2,24 & 227 & 2,02 \\
1 & 3,22 & 221 & 2,79 \\
2 & 4,57 & 212 & 3,91 \\
3 & 6,41 & 201 & 5,51 \\
4 & 8,80 & 185 & 7,80 \\
5 & 11,8 & 165 & 11,0 \\
6 & 15,2 & 140 & 15,5 \\
7 & 18,2 & 112 & 21,5 \\
8 & 22,2 & 80,2 & 29,5 \\
9 & 25,0 & 47,1 & 39,8 \\
10 & 26,8 & 13,7 & 52,6 \\
11 & 27,3 & $9,40 \mathrm{E}-2$ & 58,4 \\
12 & 27,3 & $1,01 \mathrm{E}-4$ & 58,4 \\
13 & 27,3 & $5,44 \mathrm{E}-6$ & 58,4 \\
\hline
\end{tabular}

The optimization process using higher concentrations of yeast, was also observed by Lopes et al. (2005) in the production of fermented fruit from the cactus. By using a higher initial concentration of yeast, was achieved the best result of productivity (ethanol concentration per time). 
Regarding the initial substrate concentration, when it was $230 \mathrm{~g} \mathrm{~L}^{-1}$, it was obtained an increase in concentration of product formed and a small amount of residual substrate. The results for this test are in Table 5. In counterpart, an initial concentration of $240 \mathrm{~g}$ of substrate. $\mathrm{L}^{-1}$, leave a substrate residual of $5,41 \mathrm{~g} \mathrm{~L}^{-1}$ in 13 hours of fermentation, and an initial concentration $250 \mathrm{~g} \mathrm{~L}^{-1}$, left a residual substrate of $19,3 \mathrm{~g} \mathrm{~L}^{-1}$. For these latter cases a study of a longer fermentation would be required. For this reason the results of simulations with initial concentrations of $240 \mathrm{~g}$ and $250 \mathrm{~g}$ of substrate were only mentioned here without presenting further elaboration at different process times through the tables.

Table 5. Simulation result for the concentration of the biomass, substrate and product for different times of the cassava hydrolyzate fermentation process, considering a different initial concentration of substrate

\begin{tabular}{cccc}
\hline Time $(\mathrm{h})$ & Biomass $\left(\mathrm{g} \mathrm{L}^{-1}\right)$ & Substrate $\left(\mathrm{g} \mathrm{L}^{-1}\right)$ & Product $\left(\mathrm{g} \mathrm{L}^{-1}\right)$ \\
\hline 0 & 1,12 & 230 & 2,02 \\
1 & 1,61 & 227 & 2,40 \\
2 & 2,30 & 223 & 2,95 \\
3 & 3,26 & 217 & 3,74 \\
4 & 4,58 & 208 & 4,86 \\
5 & 6,35 & 197 & 6,47 \\
6 & 8,62 & 182 & 8,72 \\
7 & 11,4 & 163 & 11,9 \\
8 & 14,6 & 139 & 16,1 \\
9 & 18,0 & 112 & 21,9 \\
10 & 21,3 & 82,6 & 29,4 \\
11 & 24,0 & 51,1 & 39,1 \\
12 & 25,8 & 19,0 & 2,95 \\
13 & 26,5 & 0,38 & 59,0 \\
\hline
\end{tabular}

In a study by Thatipamala et al. (1992), it was observed that the substrate concentration significantly affected product yield in batch fermentation by Saccharomyces cerevisiae. There was a drop from 0,45 to 0,30 in the overall yield of the product when the initial substrate concentration increased from 150 to $280 \mathrm{~g} \mathrm{~L}^{-1}$.

In contrast, Borges (2008) observed that increasing the sucrose concentration in the fed environment resulted in a greater production of product in a fed-batch fermentation. Likewise, Barbosa et al. (2010) observed that the addition of sucrose in the raw material may increase the yield of ethanol on its kinetic study of the production of ethanol by Saccharomyces cerevisiae using whey as a substrate for the production of brandy.

A final test was conducted by varying the initial concentrations of product and maintaining the concentrations of biomass and substrate. The final concentration of product was higher in the case where the initial concentration of product was $2,5 \mathrm{~g} \mathrm{~L}^{-1}$, and that, at concentrations higher than this, production declined. This is due, most likely, by the fact that high concentrations of product exert an inhibitory effect on cell growth and, consequently, the formation of the product by the cells themselves. The results for this test can be observed in Table 6. However, the yield from this process had no significant change compared to the initial concentration of 2,02 , thus it is not 
feasible to start a fermentative process which initially already has a certain greater amount of product.

Table 6. Simulation result for the concentration of the biomass, substrate and product for different times of the cassava hydrolyzate fermentation process, considering a different initial concentration of product

\begin{tabular}{cccc}
\hline Time $(\mathrm{h})$ & Biomass $\left(\mathrm{g} \mathrm{L}^{-1}\right)$ & Substrate $\left(\mathrm{g} \mathrm{L}^{-1}\right)$ & Product $\left(\mathrm{g} \mathrm{L}^{-1}\right)$ \\
\hline 0 & 1,12 & 227 & 2,5 \\
1 & 1,60 & 224 & 2,88 \\
2 & 2,27 & 219 & 3,43 \\
3 & 3,21 & 214 & 4,20 \\
4 & 4,48 & 206 & 5,31 \\
5 & 6,18 & 195 & 6,88 \\
6 & 8,36 & 180 & 9,08 \\
7 & 11,0 & 162 & 12,1 \\
8 & 14,1 & 140 & 16,2 \\
9 & 17,4 & 114 & 21,8 \\
10 & 20,5 & 84,8 & 29,0 \\
11 & 23,2 & 54,4 & 38,2 \\
12 & 25,1 & 23,0 & 49,7 \\
13 & 25,9 & 0,958 & 59,0
\end{tabular}

The inhibition caused by the product, is also a likely explanation of Neto et al. (2006) to the decrease in ethanol production velocity in alcohoolic fermentation of cashew wine, after 10 hours of the process.

\subsection{Optimization}

The results of the optimization consists in submitting the values of the kinetic parameters obtained from the literature and the same supplied by the program. The difference between the theoretical values (calculated by the adjustment program) and those in the literature, provides an error value $\mathrm{F}$, which will be presented and discussed below.

As can be seen from Table 7, the parameters set by the program had good similarity with those obtained in the literature (BORZANI et al., 2001). This fact is justified by the value of the error $\mathrm{F}$ being equal to 2,87 , that is, a value considered small when it comes to the complexity of kinetic descriptions. Thus, a model must be formulated with approximations, since it is not possible to formulate a model that includes all the features and cellular details (STREMEL, 2001 and PACHECO, 2010).

Table 7. Comparison of the parameter adjusted values with the ones provided by literature

\begin{tabular}{ccc}
\hline Parameter & Literature values $^{\text {a }}$ & Program values \\
\hline$Y_{X / S}$ & 0,215 & 0.245 \\
$K_{s}$ & 6,16 & 6.12 \\
$K_{s}{ }^{\prime}$ & 7,88 & 8.06 \\
$\mu_{p a}$ & 2,08 & 2.34 \\
$\mu_{x a}$ & 0,672 & 0.448 \\
\hline
\end{tabular}

Source: BORZANI et al., 2001. 
Despite all this complexity, Pacheco (2010) adjusted the kinetic parameters of a tubular reactor with external recirculation upflow and a strain of yeast flocculation characteristics, obtaining a residue of 0,0365 . This residue results from the difference between the values of the experimental kinetic parameters and calculated by the model through the minimizing of the sum of squares of the differences.

Kinetic parameters were also satisfactorily adjusted by Andrietta et al. (2003) for a process of ethanol production in fed batch. In his work the parameters were adjusted through an adjustment routine developed in Delphi with Paradox database. This program is also based in the minimizing of the sum of squared error between the values calculated by the model and those obtained experimentally. In the kinetic model used by Andrietta et al. (2003) was added the term of substrate inhibition. Since the model adjusted satisfactorily the experimental data, it was concluded that the inhibition caused by the substrate was relevant.

Similarly, in the program of adjustment of parameters presented on this article, the kinetic model also allowed the characterization of the process. This is due to the fact that even with the removal of the term representing the product inhibition in the equations of specific speeds, the factor of the difference between the experimental and theoretical values remained small. Therefore, it was possible to observe that the inhibition constant caused by the product may be disregarded.

\section{Conclusion}

Through this study on programming in FORTRAN, it was possible to observe that the developed simulation program represents very well a fermentation process from hydrolyzed of cassava. Thus, this program can be used to predict response of the reactor to changes in operating conditions and scaling without additional costs involved in constructing and operating a pilot plant. Furthermore, using the program provides a reduction of the time that would be necessary to obtain the same observations empirically.

The adjustment program also provided the values of the kinetic parameters with a small error. Furthermore, the program also allowed the evaluation of the characteristics of fermentation process, because it was noticed that the inhibition caused by the product in this case can be disregarded.

Therefore, programming is a great way to study the fermentation processes efficiently and practically. 


\section{Simbols used}

\begin{tabular}{|c|c|c|}
\hline $\mathrm{C}_{6} \mathrm{H}_{12} \mathrm{O}_{6}$ & & Glucose \\
\hline $\mathrm{C}_{2} \mathrm{H}_{5} \mathrm{OH}$ & & Ethyl alcohol (ethanol) \\
\hline $\mathrm{CO}_{2}$ & & Carbon dioxide \\
\hline$S$ & {$\left[\mathrm{~g} \mathrm{~L}^{-1}\right]$} & Substrate concentration \\
\hline$P$ & {$\left[\mathrm{~g} \mathrm{~L}^{-1}\right]$} & Product concentration \\
\hline$X$ & {$\left[\mathrm{~g} \mathrm{~L}^{-1}\right]$} & Biomass concentration \\
\hline$d S / d t$ & {$\left[\mathrm{~g} \mathrm{~h}^{-1} \mathrm{~L}^{-1}\right]$} & Rate of substrate consumption \\
\hline$d P / d t$ & {$\left[\mathrm{~g} \mathrm{~h}^{-1} \mathrm{~L}^{-1}\right]$} & Rate of product formation \\
\hline$d X / d t$ & {$\left[\mathrm{~g} \mathrm{~h}^{-1} \mathrm{~L}^{-1}\right]$} & Growth rate of the microorganism \\
\hline$(d P / d t)_{1}$ & {$\left[\mathrm{~g} \mathrm{~h}^{-1} \mathrm{~L}^{-1}\right]$} & Rate of product formation at instant 1 \\
\hline$t_{1}$ & [h] & Instant 1 \\
\hline$(d P / d t)_{2}$ & {$\left[\mathrm{~g} \mathrm{~h}^{-1} \mathrm{~L}^{-1}\right]$} & Rate of product formation at instant 2 \\
\hline$t_{2}$ & [h] & Instant 2 \\
\hline$\mu_{x}$ & {$\left[\mathrm{~h}^{-1}\right]$} & Specific growth velocity of the microorganism \\
\hline$\mu_{s}$ & {$\left[\mathrm{~h}^{-1}\right]$} & Specific velocity of substrate consumption \\
\hline$\mu_{p}$ & {$\left[\mathrm{~h}^{-1}\right]$} & Specific velocity of product formation \\
\hline$Y_{X / S}$ & {$\left[\mathrm{~g} \mathrm{~g}^{-1}\right]$} & Factor conversion of substrate to cells (biomass yield) \\
\hline$X_{0}$ & {$\left[\mathrm{~g} \mathrm{~L}^{-1}\right]$} & Initial concentration of biomass \\
\hline$S_{0}$ & {$\left[\mathrm{~g} \mathrm{~L}^{-1}\right]$} & Initial concentration of substrate \\
\hline$Y_{P / S}$ & {$\left[\mathrm{~g} \mathrm{~g}^{-1}\right]$} & Factor conversion of substrate to product (product yield) \\
\hline$P_{0}$ & {$\left[\mathrm{~g} \mathrm{~L}^{-1}\right]$} & Initial concentration of product \\
\hline$\mu$ & {$\left[\mathrm{h}^{-1}\right]$} & Specific growth velocity of the microorganism \\
\hline$\mu_{\text {máx }}$ & {$\left[\mathrm{h}^{-1}\right]$} & Maximum specific velocity of microorganism growth \\
\hline$K_{S}$ & {$\left[\mathrm{~g} \mathrm{~L}^{-1}\right]$} & $\begin{array}{l}\text { Saturation constant; substrate concentration at which the specific } \\
\text { growth velocity is half of its maximum value }\end{array}$ \\
\hline$\mu(S, P)$ & {$\left[\mathrm{h}^{-1}\right]$} & Specific velocity of cell growth \\
\hline$K_{S}$ & [g.L $\left.\mathrm{L}^{-1}\right]$ & $\begin{array}{l}\text { Substrate concentration at which the specific velocity of product } \\
\text { formation is half of its maximum value }\end{array}$ \\
\hline$P^{\prime}$ & {$\left[\mathrm{g} \mathrm{L}^{-1}\right]$} & Product concentration which completely inhibits cell growth \\
\hline A & & Exponent for inhibiting cell by ethanol \\
\hline$\mu_{x a}$ & {$\left[\mathrm{~h}^{-1}\right]$} & Maximum specific velocity of microorganism growth \\
\hline$\mu_{p a}$ & {$\left[\mathrm{~h}^{-1}\right]$} & Maximum specific velocity of product formation \\
\hline$K_{i}$ & {$\left[\mathrm{~g} \mathrm{~L}^{-1}\right]$} & Inhibition constant of cell growth by the substrate \\
\hline$K_{i}^{\prime}$ & {$\left[\mathrm{g} \mathrm{L}^{-1}\right]$} & Inhibition constant of product formation by the substrate \\
\hline$K_{p}$ & {$\left[\mathrm{~g} \mathrm{~L}^{-1}\right]$} & Constant Inhibition cell growth by the product \\
\hline$K_{p}$ & {$\left[\mathrm{~g} \mathrm{~L}^{-1}\right]$} & Inhibition constant of product formation by the product \\
\hline$F$ & & Factorial \\
\hline$A(I)$ & & Error calculated at each time $(I)$ \\
\hline$X t(I)$ & {$\left[\mathrm{g} \mathrm{L}^{-1}\right]$} & Theoretical value of $X\left(\mathrm{~g} . \mathrm{L}^{-1}\right)$ for time $(I)$ calculated by the program \\
\hline$X e(I)$ & {$\left[\mathrm{g} \mathrm{L}^{-1}\right]$} & Value obtained in the literature for $X^{*}\left(\mathrm{~g} \cdot \mathrm{L}^{-1}\right)$ in time $(I)$ \\
\hline$S t(I)$ & {$\left[\mathrm{g} \mathrm{L}^{-1}\right]$} & Theoretical value of $S\left(\mathrm{~g} . \mathrm{L}^{-1}\right)$ for time $(I)$ calculated by the program \\
\hline $\mathrm{Se}(I)$ & {$\left[\mathrm{g} \mathrm{L}^{-1}\right]$} & Value obtained in the literature for $S^{*}\left(\mathrm{~g} . \mathrm{L}^{-1}\right)$ in time $(I)$ \\
\hline $\operatorname{Pt}(I)$ & {$\left[\mathrm{g} \mathrm{L}^{-1}\right]$} & Theoretical value of $P\left(\mathrm{~g} \cdot \mathrm{L}^{-1}\right)$ for time $(I)$ calculated by the program \\
\hline$P e(I)$ & {$\left[\mathrm{g} \mathrm{L}^{-1}\right]$} & Value obtained in the literature for $P^{*}\left(\mathrm{~g} . \mathrm{L}^{-1}\right)$ in time $(I)$ \\
\hline
\end{tabular}

\section{Referências}


ALFENORE, S.; CAMELEYRE, X.; BENBADIS, L.; BIDEAUX, C.; URIBELERREA, J. L.; GOMA, G.; MOLINAJOUVE, C.; GUILLOUET S. E. Aeration strategy: a need for very high ethanol performance in Saccharomyces cerevisiae fed-batch process. Appl Microbiol Biotechnol, v. 63 n.5, p 537-542, 2004. PMID 12879304.

ANDRIETTA, S. R.; FERREIRA, E.; ANDRIETTA, M. G. S. Avaliação da Influência da Velocidade de Alimentação sobre o Rendimento e Produtividade dos Processos de Produção de Etanol Operando em Batelada Alimentada. XIV Simpósio Nacional de Fermentações. Florianópolis, 2003.

AUGUSTO, E. F. P.; BONOMI, A.; GIUDICI, R. Estratégias para ajuste de parâmetros em modelos de processos fermentativos inibidos pelo substrato e produto. In: 10. Congresso Brasileiro de Engenharia Química COBEQ, 1994. Anais. São Paulo SP Brasil, v. 2. p. 1252-1257, 1994.

BARBOSA, A. dos S.; FLORENTINO, E. R.; FLORÊNCIO, I. M.; ARAÚJO, A. dos S. Utilização do soro como substrato para produção de aguardente: estudo cinético da produção de etanol. Revista Verde, v. 5, n. 1, p. 07-25, 2010.

BORGES, P. C. S. Otimização dinâmica da fermentação alcoólica no processo embatelada alimentada. Uberlândia, MG, 2008. 141 f. Dissertation (master's degree in Chemical Engineering) - Programa de Pós Graduação em Engenharia Química - Universidade Federal de Uberlândia.

BORZANI, W.; AQUARONE, E.; LIMA, U. A.; SCHMIDELL, W. Biotecnologia Industrial, 4th ed., v. 2, Blucher, São Paulo 2001.

BORZANI, W.; AQUARONE, E.; LIMA, U. A.; SCHMIDELL, W. Biotecnologia: Tecnologia das Fermentações, 5th ed., v. 1, São Paulo: Edgar Blucher Ltda, 1992.

BUENO, T. Modelagem, simulação e controle de bioprocessos - Uma abordagem introdutória. Universidade Federal do Paraná, 2006.

CAMACHO, I. A. O. Caracterização dos resíduos do processamento de mandioca para produção de bio-etanol Revista Raízes e Amidos Tropicais. Botucatu, SP, 2009

DIEHL, F. C. Análise, controle e otimização operacional de um reator de Zymomonas mobilis com multiplicidade de equilíbrios. Porto Alegre, RS, 2009. 153 f. Dissertation (master's degree in Chemical Engineering) - Programa de Pós Graduação em Engenharia Química - Universidade Federal do Rio Grande do Sul.

HALL, R. J.; PAMMENT, N. B.; BARFORD, J. P. Biotechnol. Bioeng. v. 20, n. 3, p. 349-381, 1978.

HENRIQUES, A. W. S.; COSTA, A. C.; ALVES, T. L. M.; LIMA, E. L. Optimizatin of fed-batch processes : Challenges and solutions. Braz. J. Chem. Eng., vol. 16 n. 2, São Paulo, 1999.

LEITE, R. C. de C.; LEAL, M. R. L. V.; O combustível no brasil. Novos Estudos - CEBRAP, n. 78, p. 15-21, 2007.

LOPES, R. de V. V.; ROCHA, A. S.; DA SILVA, F. L. H.; DE GOUVEIA, J. P. G. Aplicação do planejamento fatorial para otimização do estudo da produção de fermentado do fruto da palma forrageira. Revista Brasileira de Produtos Agroindustriais, v. 7, n. 1, p. 25-32, 2005.

MATOS, L. J. B. L., FERNANDES, F. A. N., CARTAXO, S. J. M.. Modelagem de um Reator Oscilatório Contínuo para a Produção de Biodiesel. In: Albertin, M.. (Org.). Desafios da Cadeia Produtiva do Biodiesel para o Nordeste. Fortaleza: Premius, v. 1, p. 71-80, 2009.

MELLO, P. A.; PINTO, J. C. C. S. Escola Piloto Virtual Giuliano Massarani. Rio de Janeiro, 2008.

NETO, A. B. T.; DA SILVA, M. E.; SILVA, W. B.; SWARNAKAR, R.; DA SILVA, F. L. H. Cinética e caracterização físico-química do fermentado do pseudofruto do caju (Anacardium occidentale L.). Quím. Nova, v. 29, n. 3, p. 489492, 2006. DOI: 10.1590/S0100-40422006000300015.

PACHECO, T. F. Fermentação alcoólica com leveduras de características floculantes em reator tipo torre com escoamento ascendente. Uberlândia, MG, 2010. 94 f Dissertation (master's degree in Chemical Engineering) Programa de Pós Graduação em Engenharia Química - Universidade Federal de Uberlândia.

RANZAN, C.; TRIERWEILER, J. O.; MALVESSI, E.; SILVEIRA, M. M. Análise sistemática de modelos contínuos para fermentação contínua de glicose com Zymomonas mobilis. VIII-Octoberforum. Porto Alegre, 2009. 
REIS, G. B. Simulação e controle de processo de produção de levedura. São Carlos, SP, 2009. 91 f. Dissertation (master's degree in Chemical Engineering) - Programa de Pós Graduação em Engenharia Química - Universidade Federal de São Carlos.

SALLA, D. A.; CABELLO, C. Análise energética de sistemas de produção de etanol de mandioca, cana-de-açúcar e milho. Revista Energia na Agricultura, v. 25, n. 2, p. 32-53, 2010.

STREMEL, D. P. Desenvolvimento de modelos estruturados alternativos para o processo de produção de etanol. Campinas, SP, 2001. Thesis (doctorate in Chemical Engineering) - Faculdade de Engenharia Química - Universidade Estadual de Campinas.

THATIPAMALA, R.; ROHANI, S.; HILL, G. A. Effects of high product and substrate inhibitions on the kinetics and biomass and product yields during ethanol batch fermentation. Biotechnol. Bioeng, v. 40, n. 2, p. 289-297, 1992.

TOSETTO, G. M. Influência da matéria-prima no comportamento cinético de levedura na produção de etanol. Campinas, SP, 2002. 83 f. Dissertation (master's degree in Chemical Engineering) - Faculdade de Engenharia Química - Universidade Estadual de Campinas. 